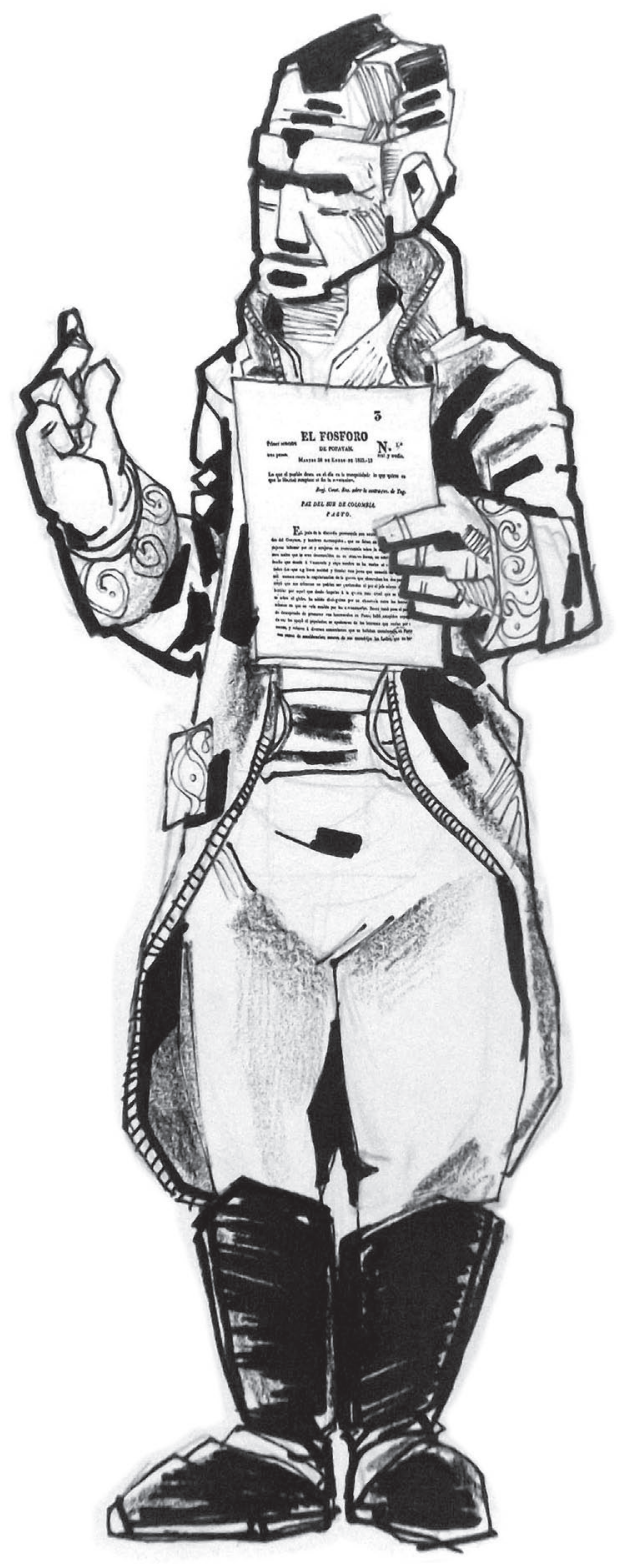

\title{
Arortesala REFLEXIÓN EN TORNO A LA HISTORIA DEL PERIODISMO EN COLOMBIA $^{1}$
}

\author{
CONTRIBUTIONS AROUND THE \\ REFLECTION OF THE HISTORY OF \\ JOURNALISM IN COLOMBIA
}

Por:

\section{Camilia Gómez Cotta}

Docente Universidad Santiago de Cali

Doctoranda en Estudios Culturales

Latinoamericanos UASB

camilia.gomez00@usc.edu.co

Resumen: Los periódicos decimonónicos que circularon entre 1819 y 1830, se constituyen en el archivo de la primera prensa republicana de Colombia. Las publicaciones anteriores a estas fechas contribuyeron a consolidar una comunidad de interpretación (Silva, 2002) letrada y criolla que aprendió a emplear libelos, gacetas, diarios, periódicos, en fin, la imprenta y sus productos como superficies discursivas en las cuales la ilustración, el despotismo borbónico o el proceso emancipatorio tenían el mayor peso enunciativo. 1819, con la Constitución de Angostura en febrero y el triunfo en la Batalla de Boyacá en agosto, fue el año de la transición, en tanto se promulgó y registró en la Ley Fundamental la "República de Colombia" por primera vez. Fue en nombre de esta letrada declaración que se siguieron liberando territorios y escribiendo periódicos....republicanos.

Palabras Clave: Prensa Republicana, Colombia, Comunicación, Ciudad Letrada, Historia del Periodismo. 
Abstract: Nineteenth-century newspapers that circulated between 1819 and 1830 , constitute the file of the first republican press of Colombia. Previous to this time publications helped to consolidate a community of interpretation (Silva, 2002) learned and Creole who learned to use libelous, journals, newspapers, the printing press and his products as discursive surfaces in which illustration, despotism Bourbon or emancipation process had the heaviest enunciative weight. 1819, with the Constitution of Angostura in February and the victory in the Battle of Boyacá in August, was the year of transition, as was promulgated and recorded in the Fundamental Law the "Republic of Colombia" for the first time. It was on behalf of this learned declaration followed liberating territories and writing Republicans newspapers.

Keywords: Republican Press, Colombia, Communication, Learned City, History of Journalism.

Acércate y contempla las palabras. Cada una tiene mil caras secretas bajo el rostro neutral.

(Sangre de Tinta) Cornelia Funke

\section{El criollato y su proyecto emancipador}

El tránsito del Antiguo Régimen a la República de Colombia, debe comprenderse ubicando el contexto geo-político del sistema-mundo moderno/colonial entre finales del siglo XVIII y las dos primera décadas del XIX. En tales coordenadas el despotismo borbón vio morir un imperio, cuyo legado incluía la especialización y burocratización del Estado; el mismo que facilitó la fabricación de subjetivaciones propias del biopoder ([1976] 1987) que velaba por la administración de la vida y el tiempo productivo de su población. Los criollos habían aprendido, incorporado, socializado y publicado estas lecciones, primero en calidad de súbditos y, posteriormente, como ciudadanos republicanos.

La Ilustración, otra impronta del despotismo borbón, vinculó las relaciones coloniales de poder a la producción, circulación y asimilación de conocimientos para su fallido proyecto imperial. Los enunciados ilustrados, en clave neogranadina, retomaban estos lineamientos y los conjugaba con la pureza de sangre de los antiguos de la tierra, pretendiendo objetividad y neutralidad discursiva que imponían sobre otros conocimientos, subjetividades y experiencias. El lugar de privilegio que se otorgaban a ellos mismos, les permitía juzgar sin ser juzgados. El punto de vista adoptado, no reconocía otro punto de vista como válido.

La producción científica ilustrada de la Nueva Granada, estaba impregnada de tal condición y con ella jerarquizaba saberes, historias, sujetos, territorios. Tal desmesura la denomina Castro-Gómez hybris del punto cero ( [2005] 2010) y permite distinguir (y diferenciar) el proyecto de emancipación letrado de los criollos, de otras manifestaciones y experiencias libertarias dadas en el territorio granadino en el Antiguo Régimen, o simultáneo al proceso que se ha enseñado en libros de texto y en clases de historia como proceso de independencia. 
A quienes lideraron la emancipación de los antiguos de la tierra se les denomina en este contexto "criollato" letrado.

Se propone comprender el "criollato" como la condición identitaria de quienes encabezaron el proceso emancipatorio en la entonces Nueva Granada, que reinvindicaba la limpieza de sangre de los nacidos en las colonias ultramarinas del reino español y como consecuencia, la no identificación ni territorial, ni identitaria con "los otros", clasificados en vastas discursividades de exclusión, gestadas y consolidadas durante la conquista y colonia territorial, simbólico y cultural en este territorio.

La no identificación del criollato con las múltiples otredades, les ubicaba en lugares distintos respecto de otros proyectos libertadores co-existentes, embrionarios y/o pre-existentes en la América Hispánica. De ahí que la emacipación criolla no representó una revolución vinculante con las heterogeneas experiencias y memorias de pueblos ancestrales, mujeres, esclavizados, pardos y demás sujetos que co-existieron en el mismo momento y que no tuvieron oportunidad ni política, ni social, ni cultural de ser incluidos en el modelo republicano que encabezaba la élite letrada.

La disímil experiencia emancipatoria puede comprenderse desde lo que Quijano ha denominado heterogeneidad histórico-estructural del poder,

En cada uno de los principales ámbitos de la existencia social cuyo control disputan las gentes, y de cuyas victorias y derrotas se forman las relaciones de explotación/dominación/conflicto que constituyen el poder, los elementos son siempre históricamente heterogéneos (...) del mismo modo, en cualquier de los otros ámbitos, la autoridad, el sexo, la subjetividad, están presentes todas las formas históricamente conocidas, bajo la primacía general de sus formas llamadas modernas: "el estado-nación", la "familia burguesa", la "racionalidad moderna". (Quijano, 2000, pp. 347-348)

Aprendices constantes del ego moderno, los miembros del criollato percibían al otro como no-ego, sólo viable para "ser conquistado, colonizado, modernizado, civilizado, como 'materia' del ego moderno" (Dussel, 1994, p. 36). Los letrados se veían a sí mismos como los únicos capaces de continuar la misión civilizatoria que la Monarquía había impuesto durante su reinado, dada la limpieza de sangre que ostentaban como herederos "naturales" y el conocimiento ilustrado en la que habían sido formados. Y es que la matriz colonial (Noboa, 2005) inaugurada con el arribo de Colón, es un referente simbólico que no se debe pasar por alto para el análisis de los acontecimientos que han tenido lugar en nuestro continente desde entonces: 
De todas maneras, Colón -hemos dichoes el primer hombre "moderno", o mejor, es el inicio de su historia. Es el primero que "sale" oficialmente (con "poderes", no siendo ya un viaje clandestino, como muchos de los anteriores) de la Europa Latina -antimusulmana-, para iniciar la "constitución" de la experiencia existencial de una Europa Occidental, atlántica, "centro" de la historia. Esta "centralidad" será después proyectada hasta los orígenes: en cierta manera, en el "mundo de la vida cotidiana (Lebenswelt)" del europeo: Europa es "centro" de la historia desde Adán y Eva, los que son también considerados como europeos, o, al menos, es considerado como un mito originario de la "europeidad", con exclusión de otras culturas.

(Dussel, 1991, p. 25) ${ }^{2}$

Propone Dussel que el yo cogito cartesiano datado en 1630, fue posible por el yo conquiro que le antecediera

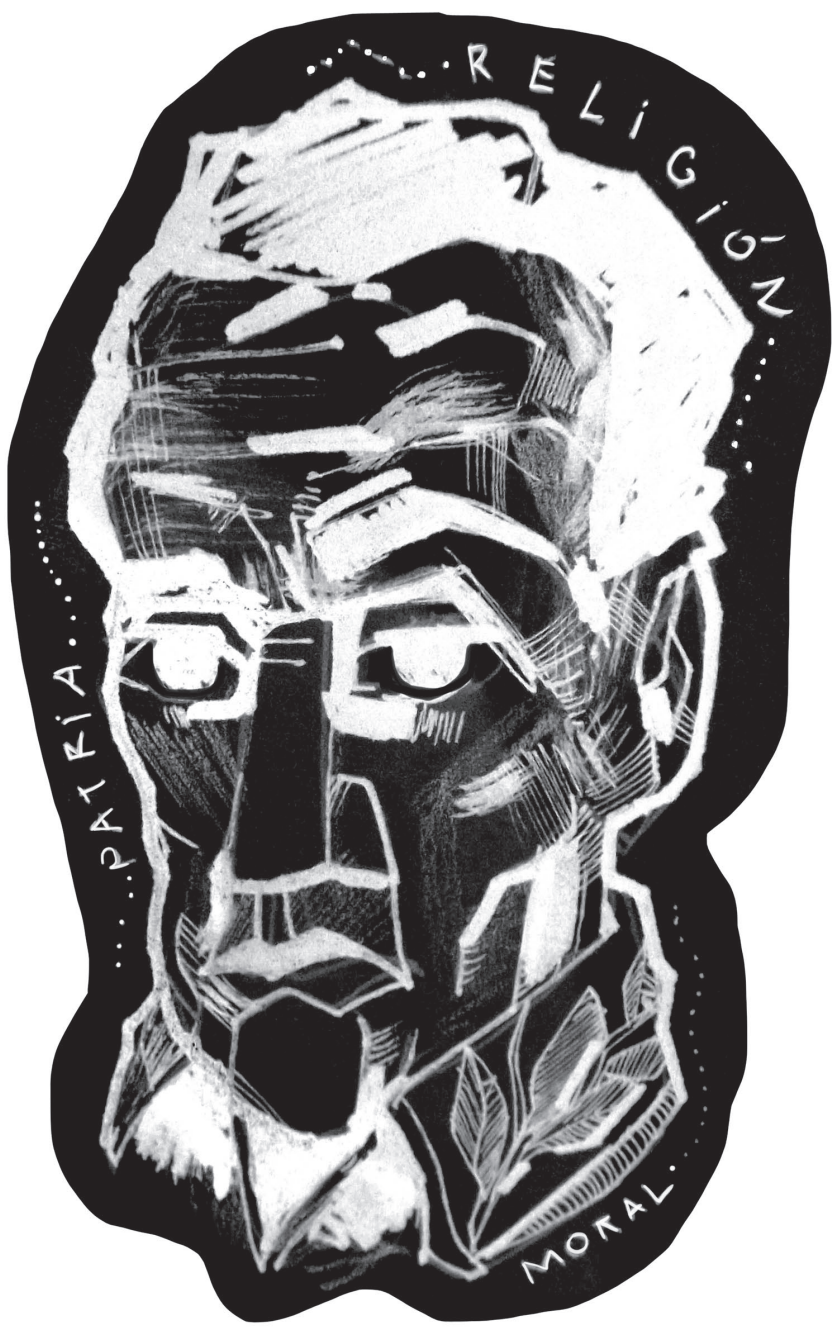
desde 1492 en la actual América Latina. A nombre de la Corona española (la primera nación moderna) y del Dios cristiano desde 1492, se fijaron mitos, otredades y jerarquizaciones que el yo cogito retomó, a nombre de la razón. Las eurocéntricas ciencias humanas del siglo XVIII, negarían a Colón y al legado español de la conquista y posterior colonia, encubriendo la Otredad que es constitutiva de la modernidad como razón moderna desde el siglo XVI e ilustrada desde el XVIII.

\section{Mitos republicanos}

Cuando se revisan los hechos y acontecimientos que posibilitaron la expulsión de la Monarquía española y la sustitución del Antiguo Régimen, hacia el Nuevo Orden en la forma estatal denominada República de Colombia, desde la colonialidad del poder (Quijano, 2000), es posible comprender que existe un horizonte colonial de larga duración (Noboa, 2005; Rivera, 1999), en el cual se ha ubicado el proceso de La Independencia, como obra exclusiva de unos pocos hombres blancos, ilustres, sabios y mártires. 
Uno de los artífices de esta creencia es el criollo José Manuel Restrepo, Secretario del Vicepresidente Santander, quien en sus escritos legó tres postulados que se han constituido como parte del mito fundante independentista: 1) la Nueva Granada como unidad política con autoridad central, 2) el 20 de julio de 1810 como fecha del levantamiento que daría origen al Estado-nación colombiano y; 3) la independencia como obra exclusiva de los criollos centralistas. Solo algunos ejemplos en contravía de estos equívocos: las confrontaciones entre las facciones patrióticas y las realistas en las costas Caribeñas, El Patía o la derrota permanente del ejército libertador en Pasto. Beligerantes momposinos que, al igual que los venezolanos, inclúan intereses y conocimientos comerciales a la causa emancipadora. La importancia que las Antillas, insulares y continentales, tuvieron de manera constante en los largos años que duró la contienda libertadora, en donde La Carta de Jamaica tuvo lugar como acontecimiento y documento histórico. Estos son algunos ejemplos que menoscaban la creencia de un solo proceso independentista resultado de unos pocos prohombres blancos. De ahí que se sostenga que la emancipación del criollato no significó una revolución vinculante con quienes denominaron "salvajes", "ignorantes", "esclavos", "iletrados" u otro adjetivo que dejara clara la distancia entre los así calificados con los civilizados, ilustres y letrados criollos.

La colonialidad de poder y su horizonte colonial de larga duración se han extendido hasta nuestros días jerarquizando no solo sujetos y territorios, sino también formas de comprender y abordar las memorias y los procesos que nos antecedieron, incidiendo en la manera en que nos explicamos el presente. Es urgente incluir en currículos académicos y en agendas investigativas que se ofrecen a los profesionales que se forman hoy, la re-visión de lo que se cree es inamovible como la historia o que se ha naturalizado como los procesos de emancipación e independencia de nuestros países, para no seguir repitiendo, sin una postura crítica los mitos del pasado que se reciclan y reinventan en el presente.

De igual forma, se hace necesario revisar cómo la historia de la prensa en particular y de los medios de comunicación en general, han contribuido en la construcción y consolidación de imaginarios, estereotipando sujetos y memorias, dejando poco espacio para la diversidad cultural existente en nuestros países. Profesionales de la comunicación críticos deben comprender la "discontinuacontinuidad" presente en la prensa como tecnología del poder (Foucault, 1977) y en los productos, de los cuales la prensa es el principal difusor de un pasado transparente, sin contradicciones, ni intereses personalistas o de clase.

\section{La letrada república de Colombia}

La república como forma estatal de gobierno, estuvo presente en la mayor parte de las antiguas colonias, con excepción, quizás, de México. Rocafuerte, escribiría el Ensayo Político. El sistema colombiano, popular, electivo y representativo (...), en 1823, cuyo interés central exponía la idea en torno a que "esta nueva parte del mundo exige un nuevo sistema de legislación, muy diferente de todo lo que se ha conocido hasta aquí pero apoyado siempre de la eterna base de formas republicanas" (citado en Aguilera, 2002, p.57). 
Como proceso de construcción de los Estados-nacionales contemporáneos, el enfoque habitual ha enfatizado, de acuerdo con Aguilar, sólo la epidermis republicana, sin lograr una real inmersión que posibilite un tratamiento más sustantivo y que permita ir más allá de concebir la república como una simple antinomia con las formas monárquicas.

La idea de la república y sus migraciones en el tiempo y el espacio han sido objeto de profundas revisiones, cuyo resultado es el cuestionamiento de los orígenes teóricos e históricos del liberalismo de los Estados nacionales modernos. Ambos, la celebrada historia del avance inexorable de la libertad y el triunfo de las teorías contractualistas han sido puestos en duda. Las implicaciones de este revisionismo para la comprensión de las fundaciones nacionales son decisivas. (Aguilar y Rojas, 2002, p. 7).

La tradicional manera de analizar el proceso republicano tiene por lo menos tres equívocos, de acuerdo con los aportes de pensador mexicano Arroyo: de un lado el tratar el concepto de manera periférica, apenas como telón de fondo para separar el Antiguo Régimen de las nuevas formas de gobierno. El segundo es hacer caber en un mismo lugar a las diversas vertientes republicanas, como si existiera solo una tradición republicana.

El tercer equívoco - en íntima relación con el primero - es que la tradición republicana ha servido teórica e históricamente subordinada a la sombra de la tradición liberal o democrática. Más aún, muchos de los legados o fundamentos republicanos se confunden con los preceptos del liberalismo. La hegemonía del debate entre liberalismo y democracia ha opacado la relevancia de las tensiones - por momentos podría hablarse de antagonismos - e intersecciones entre la tradición republicana y liberal. (Arroyo, 2002, p. 87)

Bolívar y su modelo de república enunciado en la Carta de Jamaica, por ejemplo, representa la heterodoxia republicana que debía ser guiada por los más ilustres personajes de la sociedad civil, hasta garantizar que la mayor parte del pueblo pudiese tener una suerte de mayoría de edad política. Bolívar proponía un senado vitalicio y hereditario, como salvaguarda de la república.

La libertad seguía condicionada en este régimen a una simbólica categoría política. También temía que se repitieran las funestas experiencias de la Primera República en tanto las constituciones y sus hacedores habían revelado "más un elevado idealismo que habilidad práctica de estadista” (Bushnell, [1955] 1985, p. 23).

Indiscutiblemente que se presentaron confrontaciones, no había uniformidad ni política, ni territorial aún al interior del criollato neogranadino. Los patusos defendieron su postura abiertamente realista frente a las juntas de las ciudades confederadas ubicadas en la provincia del Cauca y a las iniciativas de la élite en Quito. Nariño primero y Bolívar después fueron confrontados y perdieron siempre en Pasto. 


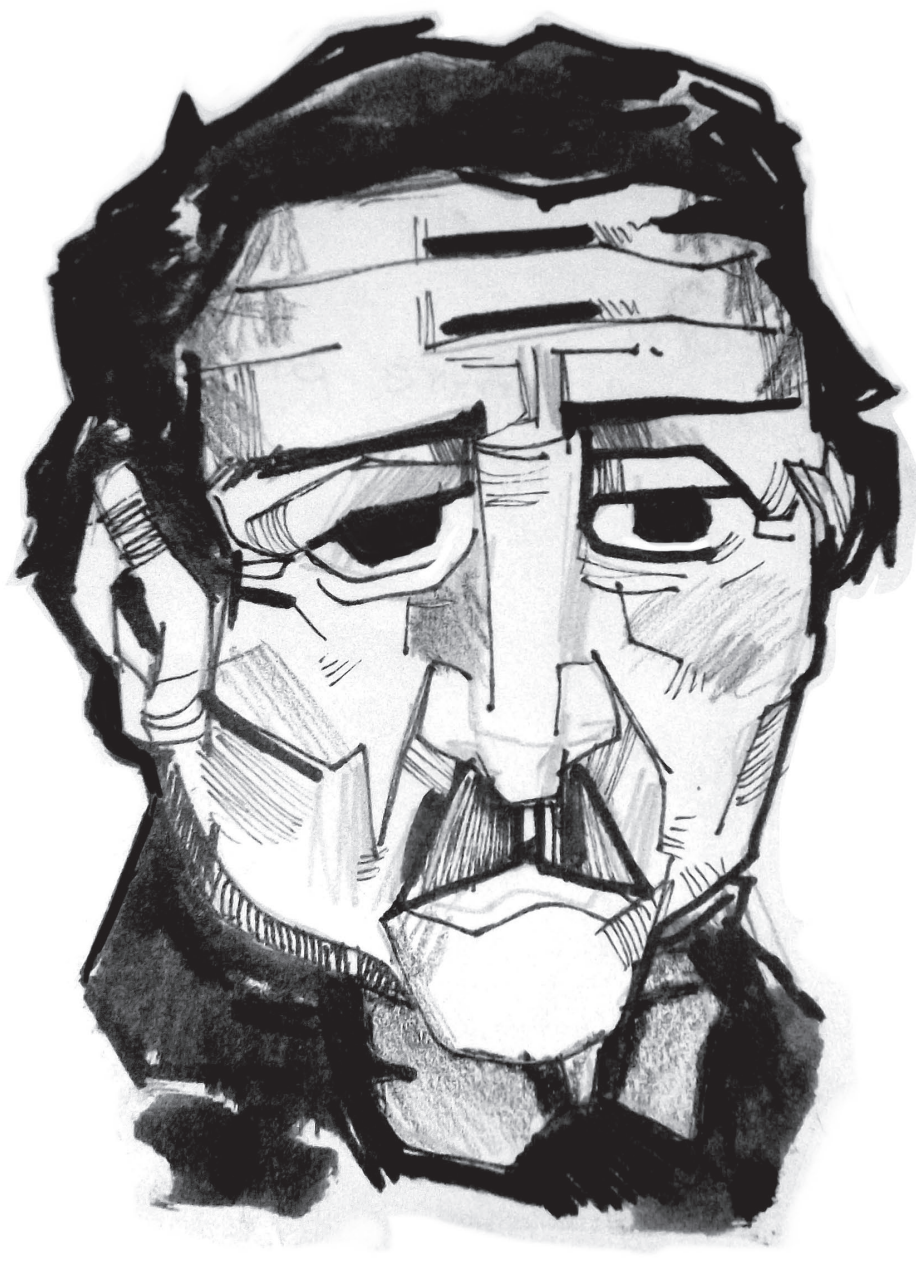

La República, en su expresión territorial, seguía siendo el archipiélago de islas, que el criollato fue incapaz de interpretar y/o integrar. Los próceres y sus huestes llevaban a cabo "un fragmentado y conflictivo movimiento dirigido por la élite y limitado a ciertas ciudades y zonas, en tanto que otras ciudades y pueblos permanecían leales a España” (Helg, 2011, p. 220). El discurso ilustrado criollo, no generó antes de la Pacificación (o Primera República), una posibilidad diferente a autonomías endebles, poco duraderas y militarmente débiles. El deseo civilizador (Rojas, 2006), no se cristalizaría sino hasta la década comprendida entre 1820 y 1830.

Más de una década que tardó en consolidarse la idea republicana en la Nueva Granada, con el desgaste estratégico, económico y el desangre que dejó a su paso, contribuyó a consolidar la idea de un partido libertador (Mejía, 2007) y a catapultar la imagen de Bolívar como la figura que garantizaba la libertad de los pueblos, aun a pesar de no incluir a los descastados, a los esclavizados, a los salvajes, a las mujeres, o a los territorios por fuera de las ciudades en la República (de letras) de Colombia; que había nacido, de acuerdo a la Ley Fundamental, promulgada en Angostura, en 1819.

Para el caso colombiano, es importante señalar que la República fue posible solo después de superar militarmente la pacificación que el español Morillo impuso a sangre y fuego entre 1815 y 1819 en el territorio disputado por el ejército patriota. Luego de casi una década se logró consolidar la República de Colombia, por lo menos en los vecindarios letrados del criollato.

En la batalla del Pantano de Vargas, el ejército liderado por Bolívar declaró libre de la monarquía española al territorio conocido hasta ese día como elVirreinato de la Nueva Granada. Meses antes, el 15 de febrero de 1819, junto a otros miembros del ejército libertador y de la sociedad civil, Bolívar había instalado el Congreso de Angostura donde se constituyó la República de Colombia integrada por tres departamentos: Venezuela, Nueva Granada y Quito (del Sur). La colonial Santa Fe, fue renombrada como Bogotá, capital del nuevo estado. Por vez primera, se escribía el nombre de Colombia en documentos oficiales. Los recién expropiados territorios coloniales, tenían un nombre republicano. 
No toda Colombia era libre. La contienda militar española con Morillo a la cabeza, no se terminaba de definir; Venezuela lideraba la independencia, mientras sólo Casanare era la única provincia libre en Nueva Granada y Quito seguía en manos realistas. Pese a ello, la Constitución de Angostura o Ley Fundamental ${ }^{3}$, envistió a Simón Bolívar como presidente y a Francisco de Paula Santander como Vicepresidente de la naciente república. La redacción de la Ley Fundamental y la avanzada militar hacían parte de la misma estrategia criolla: vincular el discurso legislativo y castrense a la naciente república. Letra y poder bélico, era el tiempo de la ciudadanía y de las huestes republicanas.

Colombia era más un deseo que una realidad: Quito seguía bajo el mando español, en el Caribe las ciudades realistas como Santa Marta se resistían al proyecto republicano. Pasto había demostrado con un ejército aguerrido y aliado a la guerrilla patiana, que no cedería fácilmente ante la facción libertadora. En Venezuela la causa patriótica se había establecido, salvo algunos levantamientos en Puerto Cabello, pero requería de las tácticas letradas para justificar el cambio que representaba la forma estatal republicana. Con todo, el Congreso de Angostura y la redacción de la Ley Fundamental tuvieron lugar. El encabezado signaba el nuevo nombre y régimen republicano de Colombia:

Ley Fundamental de la REPUBLICA DE COLOMBIA

El soberano CONGRESO de VENEZUELA, à cuya autoridad han querido voluntariamente sujetarse los PUEBLOS de la NUEVA GRANADA recientemente libertados por las ARMAS de la REPUBLICA: CONSIDERANDO- $1^{\circ}$ Que reunidas en una sola Repùblica las Provincias de Venezuela y de la Nueva Granada tienen todas las proporciones y médios de elevarse al mas alto grado de poder y prosperidad: $2^{\circ}$ Que constituidas en Repúblicas separadas, por mas estrechos que sean los lazos que las unan, bien lejos de aprovechar tantas ventajas, llegarían difícilmente à consolidar y hacer respetar s Soberanía: $3^{\circ}$ Que estas verdades altamente penetradas por todos los hombres de talentos superiores, y de un ilustrado patriotismo, habían movido los Gobiernos de las dos Repúblicas à convenir en su reunión, que las vicisitudes de la guerra impidieron verificar. Por todas estas consideraciones de necesidad y de interés reciproco, y con arreglo al informe de una Comisión Especial de Diputados de la Nueva-Granada y de Venezuela, en el NOMBRE y baxo los Auspicios del SER SUPREMO. Ha decretado y decreta la siguiente Ley Fundamental de la REPUBLICA DE COLOMBIA (...)

El numeral $5^{\circ}$ expone la configuración de la nueva República:

La REPUBLICA de COLOMBIA se dividirá en tres grandes Departamentos, Venezuela, Quito y Cundinamarca, que comprenderà las Provincias de la Nueva Granada, cuyo nombre queda desde hoy suprimido. Las capitales de estos Departamentos serán las ciudades de Caràcas, Quito, y Bogotá, quitada la adición de Santafe $(. . .)^{4}$. 
En unos pocos artículos, se re-nombraban urbes y jerarquías, tareas aprendidas por los herederos de la ciudades construidas desde el yo conquiro de la primera modernidad española.

Los criollos republicanos eran diestros descendientes del dominio que espadas y misiones medievales habían impuesto a culturas, personas, tradiciones y territorios en el Nuevo Mundo. Los ilustres libertadores se habían beneficiado del legado moderno/colonial que jerarquizaba saberes y clasificaba en castas a los seres humanos. Conocían y manejaban la distribución del damero colonial que organizaba los espacios y centralizaba el poder.

Los diputados patriotas manejaban con altivez los trazados or togonales de la arquitectura monárquica, la misma que había dispuesto alrededor de la plaza relaciones de poder que no necesitaban ser leyes para ser cumplidas,

La traslación del orden social a una realidad física (...) implicaba el previo diseño urbanístico mediante los lenguajes simbólicos de la cultura sujetos a concepción racional. Pero a ésta se le exigía que además de componer un diseño, previera un futuro (...) El futuro que aún no existe, que no es sino sueño de la razón, es la perspectiva genética del proyecto" (Rama, 1998, p. 20).

Trescientos años de ocupación española habían signado en cuerpos y ciudades escalas y categorías sociales que lucían por encima de los trajes y los nuevos roles republicanos.

Quienes empezaban a legislar en nombre del pueblo, habían aprendido que la misión civilizatoria del naciente Estado, se fundaba sobre los cimientos del Antiguo Régimen. No en vano habían asimilado las lecciones de cómo administrar funciones sociales y relaciones familiares para acceder a los espacios de poder.

El 20 de julio de 1810 empezó el 6 de agosto de 1538. Unas cuantas familias criollas, dueñas de las tierras, los resguardos, el cabildo, las contadurías, los títulos y las prerrogativas hicieron la revolución, pero en la Nueva Granada, a diferencia de las demás naciones "una sola familia” abonó el terreno y empuñó el mando. Los apellidos que fueron clave en las jornadas revolucionarias, los Caicedo, Vergara, Vélez Ladrón de Guevara, Santamaría, Camacho, Prieto Salazar, Ortega, Lozano de Peralta, Álvarez del Casal, González Manrique Flórez, Rivas, Morales, Galavís, Groot, Nariño, Rodríguez Lago y García Tejada, entre otros, se entretejen uno a uno hasta formar una familia en la que todos firman una nómina oficial. (Abella en Marín, 2008, p. 17) 
La limpieza de sangre no se modificaba con el nuevo orden. Sabían que habitaban lugares de privilegio que les otorgaba ser parte de la comunidad letrada en tanto manejaban la técnica para redactar edictos, leyes, protocolos, normas policivas. Como habitantes de la ciudad escrituraria (Rama, 1998), los criollos habían tenido acceso a la gramática de prebendas y concesiones virreinales, así como a todas las formas signadas de poder y sabían que la facultad escrituraria "era indispensable para la obtención o conservación de los bienes, utilizando canónicos modos lingüísticos que se mantenían invariables durante siglos" (Rama, 1998, p. 44).

Orden y escritura, tradiciones del proyecto moderno/colonial, forjados desde la Conquista y sostenidos en la Colonia, eran herramientas útiles en la república. El reordenamiento gubernamental requería al pueblo como soldado, o como figura discursiva en alocuciones libertarias de plazas y ciudades, pero debía conservarse el complejo tejido de castas de las otredades a civilizar; la superioridad étnica criolla heredada por los lazos directos con Europa que la limpieza de sangre representaba, no hacía parte de los cambios que traían consigo las leyes del nuevo Estado.

La República de Colombia de 1819, amalgamaba series discursivas que representaban relaciones de semejanza, vecindad, igualdad, pero también de diferenciación, alejamiento y distancia entre el pueblo y la dirigencia, entre los plebeyos y los ciudadanos. Lugares y discursos eran parte de las estrategias ilustradas adaptadas al proyecto libertario como expresión del deseo civilizador y de la economía política republicana "los significados atribuidos a ciertos eventos, la preeminencia de ciertas representaciones, el silencio alrededor de otras, son el resultado de la interacción de poder desiguales" (Rojas, 2001, p. 183).

Los periódicos publicados entre 1819 y 1830 , fueron parte de los dispositivos que la colonialidad del poder desplegó en clave republicana, para posicionar las formaciones discursivas sobre las que se edificaron los principios del Nuevo Orden estatal. El análisis del archivo permite observar algunos enunciados publicados en torno a los cuales la prensa republicana continuaba la discriminación y distanciamiento sobre los descastados, esclavizados y otros sujetos subalternos que la ciudad letrada, el ego moderno y la matriz colonial, habían impuesto de tiempo atrás.

\section{De fisuras a roturas letradas}

Hasta 1826 la República de Colombia no tuvo mayor amenaza separatista dentro del partido libertador, denominado así por el ya mencionado paisa José Manuel Restrepo. Bolívar representaba la expulsión de España en el territorio colombiano. Sin embargo "los efectos prácticos inmediatos de la Ley Fundamental y de la mayor parte de las otras leyes promulgadas por el Congreso, fueron débiles, salvo en las vecindades inmediatas del Congreso" (Bushnell, [1954] 1985, p. 30). Sin embargo, no eran homogéneos los intereses al interior del vecindario letrado. 
En el partido libertador se empezaron a notar facciones y entre los mismos beneméritos criollos, existían conflictos. Por mencionar un ejemplo, Nariño y Santander se enfrentaron en varios momentos hasta la muerte del primero. Cada uno representaba dos generaciones y visiones distintas sobre la manera de concebir, dirigir y consolidar La República. Sus posturas, opuestas siempre, representaban visiones igualmente opuestas sobre el naciente estado republicano. De otro lado,

(...) Nariño era un prominente bogotano y Santander un hombre, que, venido de provincia, gobernaba la metrópolis neogranadina. El resentimiento de los bogotanos solo pudo aumentar con el hecho de que muchos de los funcionarios principales también eran provincianos como los Azuero, del Socorro y Francisco de Soto de Pamplona. (Bushnell, [1954] 1985, p. 85)

De forma genérica podría decirse que las discrepancias letradas incluían antagonismos regionales, o, la férrea convicción de los santafereños en tener una posición más preponderante en el gobierno, en tanto a pesar del cambio de nombre, Bogotá era el lugar de residencia de quienes sentían que se debían otorgar más cargos y privilegios republicanos a los patricios santafereños.

Parte de estas posturas se reflejaron en la prensa. A manera de ejemplo, una réplica y contraréplica entre El correo de Bogotá y El Insurgente:

Se ha puesto al papel el título de insurgente dándose por motivo que con esta denominación ha sido marcado por los tiranos y opresores de las naciones todo el que ha hecho esfuerzo en cualquier tiempo fiara promover la libertad del pueblo, instruirlo, en sus deberes y derechos y rectificar la opinión pública.

Pero por esta misma razón creo que de ninguna manera puede convenir aquel título a un papel que sale en medio de un pueblo, que tiene instituciones liberales, y donde no gobiernan tiranos opresores que se hayan usurpado la autoridad, sino los mismos que destruyeron a los usurpadores y que llamaron a los representantes de estos pueblos para que se diesen leyes y escojiesen magistrados (...) pero si se propusiese verdaderamente atacar al gobierno e instituciones sin mucha moderación y muy buenas razones, se le debería titular, mas bien que insurgente, el demagogo, el anarquista (...) el epígrafe dice; las naciones se conquistan por la fuerza, se mantienen por la justicia, y se destruyen por la violación de las leyes y corrupción de las costumbres.

La primera máxima me parece absurda, y digna sólo de Maquiabelo, de Hobbes y aun de Grocio. Ni la conquista ni la fuerza darán nunca un derecho; jamás serán un título legitimo de adquisición; ellas serán siempre una injusticia, una violencia, una usurpación. Las naciones nunca serán de derecho el patrimonio de ningún conquistador. Por 
otra parte las naciones nunca se conquistan a sí mismas (...) Asi, pues, mi amigo, aunque una nación sea conquistada de hecho con la fuerza, este hecho nunca produce un derecho, que solo puede emanar de la voluntad popular, del pacto social. (Correo de la ciudad de Bogotá. Capital de la República. No. 159. Agosto 08 de 1822)

A lo que El Insurgente responde:

Mi querido amigo: ¿has visto la comedia de representación en el correo de Bogotá Núm. 159 en la que varios personajes haciendo un mismo papel, ó uno haciendo muchos, combate al Insurgente? (...) dime si hay en ellos algo de substancia, si hallas alguna línea sobre que puedas detenerte, y si esas personalidades quieren decir algo contra el periódico, ó son de alguna utilidad para el publico.

Le pareció a un Señor, escandaloso el título de Insurgente en una República, en un Pais, en un continente en donde todos lo somos, y hemos hecho de el un título glorioso; Insurgente es el inmortal Bolivar contra la opresión, contra la tiranía española (...) ¿Y qué importa al público que el Editor sea blanco ó negro, cojo o tuerto? ¿Qué certeza tiene el articulista de que el Autor del Periódico és el General Nariño? !Insensatos! midiendo las almas de los demás Ciudadanos por sus almas serviles, las ideas de los otros por sus mesquinas ideas, creen que en Colombia solo es conocido el General Nariño el lenguaje de la libertad.

Pudo ser en otro tiempo; pero desde que este suelo ha sido empapado en sangre por la libertad, su idioma y osadia ha sido, es y será demasiado conocido en la República aun que ignorado de algunos esclavos aduladores miserables que encorvados hacia la tierra no calculan si no sobre su sueldo e intereses, que harán el apoteosis del latrocino y la tiranía, si conviniere á su mejor bien estar. (El Insurgente. No. 3. Trimerstre 1. Agosto 25 de 1822) ${ }^{5}$

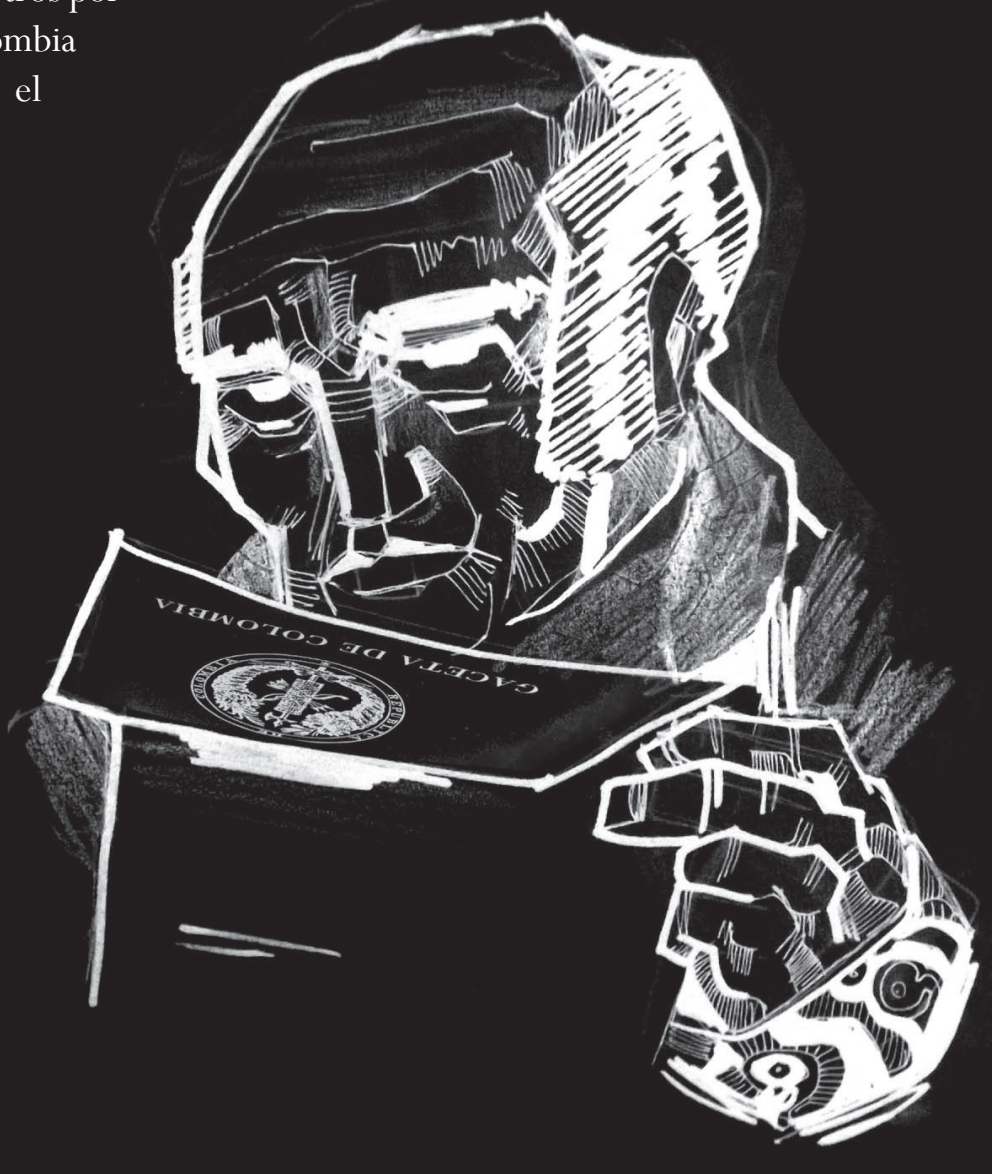


El conjunto de enunciados formado sobre un horizonte de civilidad, presentan dos relatos de la República de Colombia: las sentencias del Correo, dan cuenta de un orden establecido, liberal, que representa la voluntad de un pueblo el cual decidió el pacto social (republicano). En el Insurgente se lee otra república: una comedia de un personaje que representa varios papeles, donde se observa la opresión y la tiranía. La pluma del segundo ejemplo revela la insensatez, la adulación y el servilismo de quienes, anteponen intereses personales y sueldos, antes que los principios libertarios e insurgentes que encarna Bolívar.

Debe señalarse que El Correo de la Ciudad de Bogotá, hizo eco del ideario liberal encarnado por Santander (posible blanco de la frase "la comedia de representación en el correo de Bogotá Núm. 159 personajes haciendo un mismo papel, o uno haciendo muchos...) y que El Insurgente, era vocero de la facción federalista que representaba Nariño.

El choque entre los letrados hacía parte del registro periodístico, sin embargo no era la única superficie en la cual circulaban este tipo de tensiones. Las leyes, los decretos, las formas de concebir la instrucción pública, las relaciones con la iglesia, con España, con Haití y con las mismas regiones, hacían parte de la cotidianidad del mundo letrado y sus disputas ilustradas. La red de los múltiples discursos que circulaban en la República de Colombia, así como algunas de las prácticas discursivas que las constituían junto a sus enunciados, las elecciones temáticas y las aparentes contradicciones esbozaron las regularidades sobre las cuales es posible afirmar que se formó la primera prensa republicana en Colombia.
La prensa facilitó la circulación y la asimilación del discurso republicano, con sus normas y nuevo orden sociopolítico:

Los términos derechos, ciudadano, representación, soberanía, libertad, igualdad, república, elecciones, congreso y constitución se dijeron, se imprimieron y se leyeron en diversos espacios públicos, conformando un repertorio distinto de conceptos y palabras. Estas palabras existían y se usaban en las sociedades coloniales pero tenían significados diferentes y, sobre todo, no constituían un conjunto interrelacionado e inseparable. (Garrido, 2010, p. 8)

\section{Prensa Republicana}

La historia de la prensa en el territorio neogranadino es relativamente conocida: breve Aviso del Terremoto, sucedido por la Gaceta de Santafé, que antecedió El Papel Periódico de Santafé de Bogotá, este último, con una frecuencia semanal y todos bajo el gobierno Borbón, publicados antes de finalizar el siglo XVIII. En Quito pueden mencionarse Primicias de la cultura de Quito.

A principios del XIX, bajo la tutela del virrey y la censura imperial, serían publicados Correo Curioso erudito, económico y mercantil; El Redactor Americano: Periódico del Nuevo Reyno de Granada; Semanario de la Nueva Granada; El Alternativo del Redactor Americano; Noticias Públicas de Cartagena de Indias, Los Crepúsculos de España y Europa; La Gaceta de Caracas, todas de corte ilustrado y de enfoque monárquico. La década comprendida entre 1810 y 1819 vería el florecimiento de libelos, gacetas, diarios que exponían posturas a favor y en contra de la causa emancipadora, se pueden mencionar, entre otros, 
Diario Político de Santafé; El Argos Americano: Papel político, económico y literario de Cartagena de Indias, El Curioso de Cartagena, La Bagatela, Correo del Orinoco, éste último de factura políticomilitar, que serviría para exponer con claridad las ideas del ejército libertador y de Bolívar y Santander como sus líderes.

La década comprendida entre 1820 y 1830 , permite ver, a través de una selección de palabras que circularon en diversos espacios de sociabilidad y en soportes letrados, cómo la prensa hizo posible un archivo que contribuyó en la configuración enunciativa de la república, en coexistencia y correlación con otros campos discursivos a los que hemos denominado "vecindario letrado", como lo fueron los Congresos, con sus Constituciones, leyes y decretos; la Instrucción Pública, que propendía por un pueblo útil a la república, así como con otras superficies discursivas de la época.

La república se repetía, difundía y publicaba a partir de "palabras que circularon en todo tipo de impresos y fueron leídas y dichas por muchos. Con ellas se hacía la Independencia” (Garrido, 2010, p. 09) y los periódicos impresos fueron una de las superficies enunciativas más empleadas, permitiendo, doscientos años después de su publicación, re-visar para interpretar, a la luz de los desafíos comunicacionales y tecnológicos contemporáneos, continuidades discursivas que evidencian la colonialidad del poder en nuestros días y nuestros periódicos.

La República (de letras) de Colombia, era tributaria de las luces de la Ilustración y en ella la matriz colonial se reinventó estableciendo unidades discursivas y superficies enunciativas que contribuyeron a garantizar en la exaltación de conocimientos científicos, así como de nombres y familias beneméritas capaces de concebir tales proezas.

Sobre la matriz colonial se construyó el dominio del espacio, del tiempo, del poder y del saber en Europa y también en territorios latinoamericanos. La versión neogranadina de la Ilustración, desdeñaba, invisibilizaba y estigmatizaba saberes ancestrales, empleando con frecuencia epítetos como "salvajes", para exponer, en las vecindades letradas las diferencias y distancias existentes entre $\mathbf{l} \boldsymbol{a}$ civilización y las otredades al margen de ella como por ejemplo los incultos, los incivilizados, lo atrasados, los deficientes, los pobre, los iletrados, los salvajes, la plebe.

En tiempos más contemporáneos,

La matriz colonial aparece como un sistema ordenador y acumulativo de la acción colonial-imperial, actúa como un patrón social subyacente y permanente que constriñe continuamente nuestras acciones de la vida cotidiana y está directamente relacionada con las estructuras de poder. Se constituye a si misma como el instrumento orientador de la colonialidad del poder y del poder de la colonialidad, desde supuestos epistemológicos e interpretaciones históricas que reafirman el dogma de las concepciones lineales de progreso universal y de un imaginario de desarrollo construidos básicamente teniendo como referente a Europa, lo cual a su vez se convierte en la principal estrategia epistemológica de la expansión colonial/imperial. (Noboa, 2005, p. 61) ${ }^{6}$ 
Una de las tecnologías que contribuyó con este propósito está constituida por las publicaciones periódicas (en la colonia tardía y en la república, ambas ilustradas), como el Papel periódico de Santafé de Bogotá, que se imprimió entre 1791 y $1797^{7}$. Como acontecimiento cultural (Silva, [1988] 2004, p. 21) reflejó, de un lado, la reorganización administrativa borbónica, al tiempo que daba espacio para la circulación letrada de enunciados del criollismo ilustrado del virreinato. La revalorización de la vida, el incremento de la población como preocupación del reino, la salud, la geografía, eran temas que servían para propósitos reales y criollos.

El Papel Periódico, por ejemplo, ofreció a sus lectores noticias sobre salud, recetas de curación, informes sobre las enfermedades más frecuentes del virreinato, y recogió la iniciativa de un 'patriota', que había ofrecido un premio para quien compusiera el mejor discurso en torno al tema del aumento de la población del virreinato, la que en el diagnóstico de los ilustrados resultaba inferior a las calidades del territorio y un freno a la prosperidad (Silva, 2002, p. 440).

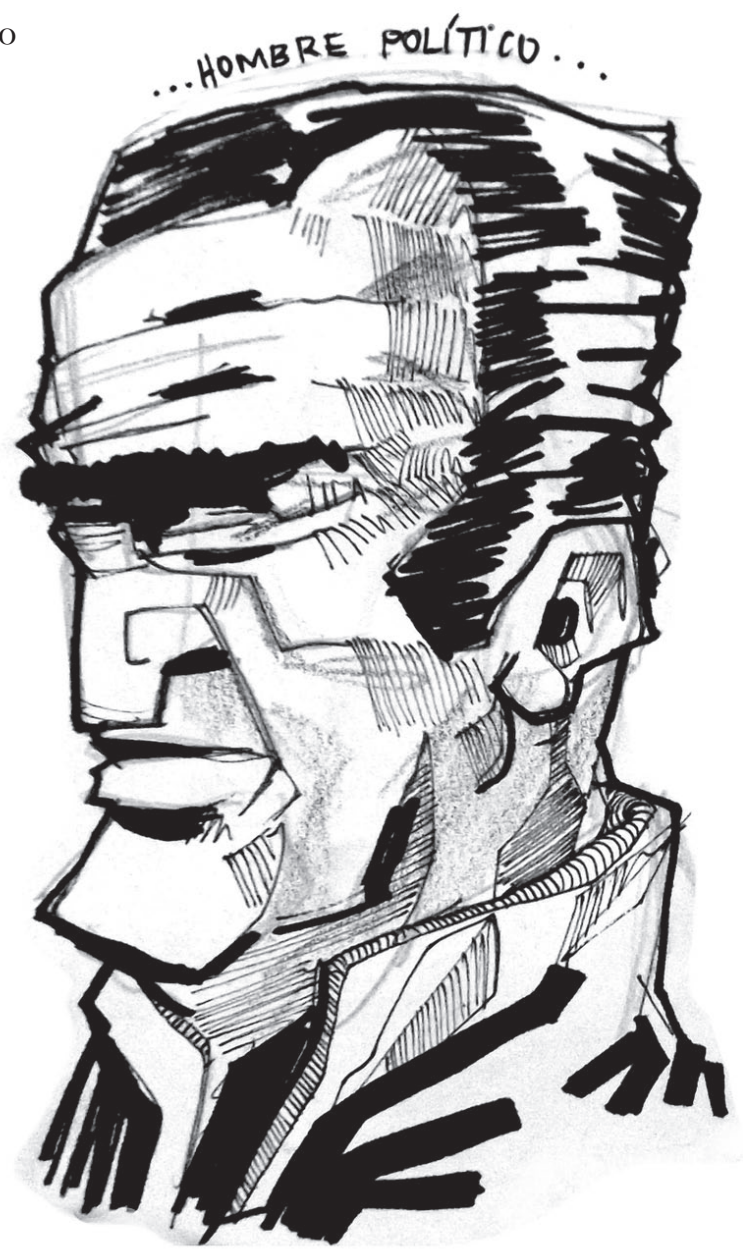

Lo propio se publicaría en el Semanario del Nuevo Reino de Granada, con "noticia del número de personas que se han vacunado en esta capital", o del mismo sobre "Estado de nacidos y muertos en la ciudad de Puente Real entre 1800 y 1808 ".

En el Correo Curioso, se abordarían conceptos más ilustrados y abstractos en torno a las probabilidades de la duración de la vida humana ${ }^{10}$; las causas de la muerte, o las relaciones entre el nuevo templo de la salud (expresión empleada en el periódico) con la prosperidad y la felicidad humana.

Si bien no se puede hablar de una opinión pública, se podría mencionar que la circulación de estos periódicos, contribuyó a formar una comunidad de información (Silva, 2006), que se fundó en la comunidad de ideas, desde un lugar de privilegiada enunciación. En la periferia del reino, la élite letrada difundía valores de la Ilustración criolla, que como lo ha señalado Castro-Gómez no fue exclusivo de Europa; en el sistema-mundo moderno/colonial coexistieron enunciados y lugares de enunciación ilustrados que se desplegaron simultáneamente. 


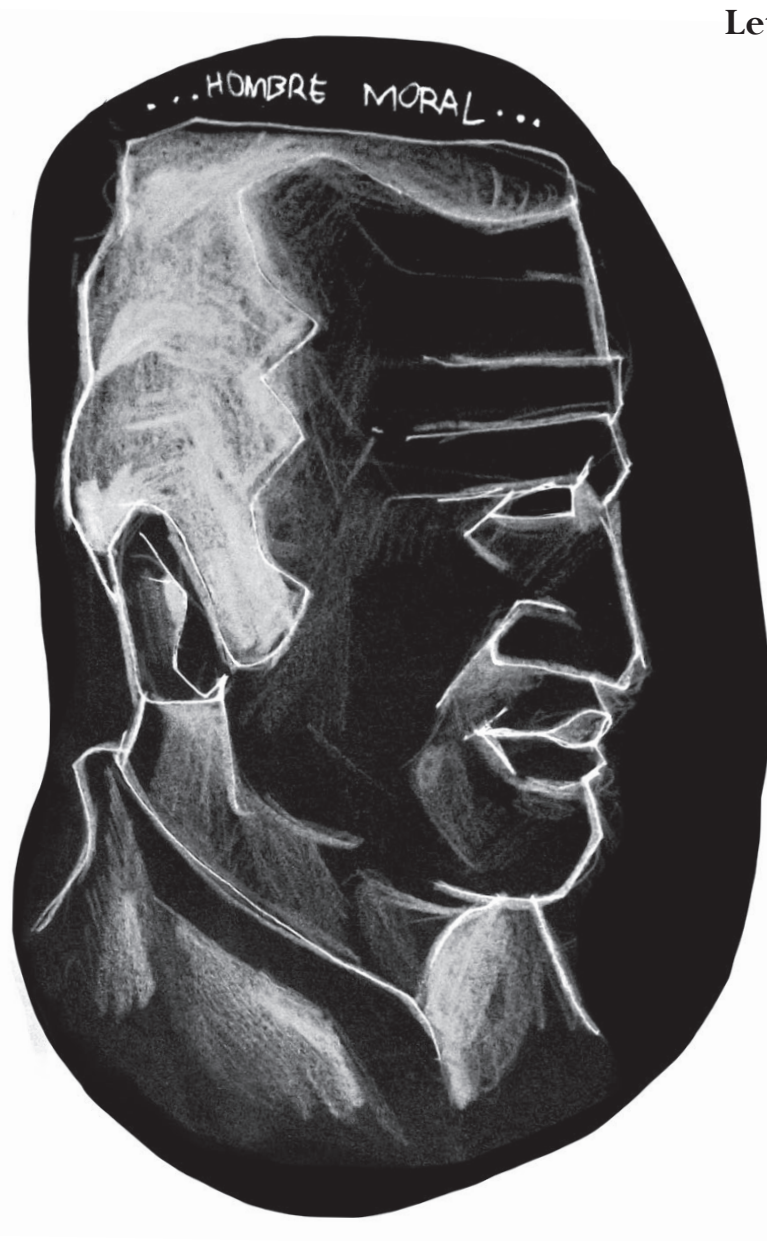

Como se mencionó antes, Santanderistas se enfrentaron contra las facciones que seguían a Nariño por más de una década, ello como consecuencia de la pugna entre Santander y Nariño que se puede rastrear hasta 1812, año en el que Santander en rango de oficial de tropa, había desertado del ejército presidido por Nariño.

Luego se enfrentaron en diversos escenarios: en congresos, en periódicos o en cargos públicos. La contienda sería heredada, aún después de la muerte de Nariño, por la facción que legaría sus principios, representados en un modelo moderadamente federalista e impulsor de lo que posteriormente llegaría a ser el partido conservador.

La prensa, tecnología de poder que acompañaría la letrada independencia, sería el último lugar de disputa. En la publicación del 5 marzo de 1823, en Los Toros de Fucha, Nariño respondía a Santander:

De cuando en cuando se nos resbalan algunas verdades, Señor patriota, como la que me sirve de epígrafe salida de su boca y aplicada por V. a V. mismo. Lo admirable es que conociendo

V. esta verdad se haya metido a escritor; y se le debería perdonar esa multitud de sandeces que nos ha ensartado, solo por esta sincera confesión. Pero tanto ha puyado V. al otro toro que al fin lo ha forzado á que salga a la plaza. ¿Así lo quiere? Pues allá va con su nombre y apellido, sin meterse de tras del bastidor.

Mis opiniones Sr. Mio, sobre federación no necesitan de sueños ni de anónimos como los que V: ellas son tan públicas tan notorias que están consignadas en todos los papeles públicos de la patria boba, en todas las paredes de San Victorino del 9 de Enero, en los corazones de los Excmos. Señores Jenerales Santander y Urdaneta que no me dejarán mentir como se hallaron presentes: en mi proyecto de constitución cuyo prospecto ó introducción anda impreso hace dos años: en todas mis conversaciones; y ultimanente en mis principios que jamás he disfrasado ni he mudado, por que los he creido fundados en la razón. Ellos son y han sido los siguientes: que el gobierno central es el mas fuerte, el mas conveniente para asegurar nuestra independencia, como que en él hay unidad de acción; pero que también es el mas espuesto al abuso. Que el gobierno federal es mas debil, mas tardío en sus deliberaciones; pero el mas adecuado para la libertad y el menos espuesto al abuso por el contrapeso que oponen las partes federadas ${ }^{11}$. 
Ambos próceres encontraron en este vecindario letrado, un espacio para promocionar ideas y posturas políticas. Santander, menos hábil con la pluma periodística intentaba retar al Precursor, en El Patriota, del 23 de febrero de 1823, en cuyo epígrafe se leía: Sal, mugilis, solque solque virilis. Salga el mugre al sol”Santander remitía, sin nombrar a Nariño, una misiva pública:

¿Qué podemos decir bajo el epígrafe anterior, que no nos vaya á grangear un buen desollineo? Bien imposible es escribir un papel que á todos guste, y a nadie moleste; pero ya que nos hemos embarsado es preciso no volver atrás, y echar al sol cosas poco limpias.

Las canas, la ambición y unos conocimientos de los tiempos de Barasorda y de Mena han pretendido tiranizar la juventud, y las luces del siglo presente. Una piedad fuera de proposito se ha atrevido à sobreponer en negocios políticos los autores eclesiásticos místicos à los escritores mas celebres, y nos han querido embaucar unas opiniones que nos parecen muy excelentes para que se lleve el diablo à la república à las leyes, y à todos nosotros, ¿Pero quienes son los reformadores que pretenden desvaratar la república actual, y edificarla à su modo, y según lo han leído el Tertuliano? Los que menos han demostrado su amor à la libertad e independencia de Colombia. ¿Quién le habrá dado exclusivo derecho para derribar de un golpe el edificio que no solo no han ayudado à levantar sinó que lo han embarazado? Cuando, donde, y á que horas es que han consultado al pueblo, y le han oído sus votos sobre si quiere federación, ò unidad en estado? Si tenían tanto amor al pueblo, y tanto celo por su felicidad ¿ porquè no lo manifestaron cuando Morillo vino a subuygarnos, ó cuando Bolivar estuvo cerca de las Cocoysas, ò que apareció en Tunja? ${ }^{12}$

El Precursor había hecho circular desde los primero años del siglo XIX, libelos y su propia traducción de los Derechos del Hombre. En años posteriores, con la retoma española sería famosa La Bagatela y, en la disputa con Santander, en 1823, Los Toros de Fucha. Por su parte, Santander escribiría en La Gaceta de Colombia, como medio institucional y El Patriota, como espacio propagandístico a favor de su facción e intereses republicanos.

Las márgenes de la emancipación republicana traían consigo herencias coloniales, entre otras, la configuración social/económica/cultural de las castas y la sociología espontánea (Bourdieu, 2000; Castro-Gómez, [2005] 2010) del criollato o limpieza de sangre.

En la república y su vida cotidiana, la sociología espontánea de la élite neogranadina era entendida como superioridad étnica y la proyectaban sobre el territorio del nuevo estado, así como en la producción de conocimientos y en los ideales políticos y civilizatorios. En el nuevo vecindario letrado constituido por la prensa republicana, algunos representantes del criollato encontrarían una nueva superficie para el correlato de la sociología espontánea o limpieza de sangre, mientras escribían en nombre de la república, el pueblo y la libertad. 
Nariño y Santander eran vecinos de la ciudad letrada y tributarios del discurso de superioridad étnica por ser hombres criollos, blancos e ilustrados. La especificidad vinculante de la limpieza de sangre les facilitaba acceder a la promoción del conocimiento científico y literario de la época. Pese a tal "vecindad letrada", los distanciamientos en la concepción y organización de la república dejaba traslucir la emergencia de una variopinta gama de subjetivaciones (militares, publicistas, beneméritos, antiguos de la tierra, libertadores, diputados, entre otros), que disputaban al interior del muro de letras del cual se reinauguraba la colonialidad del poder en las calles de la nueva República.

El criollato inauguraba, dentro del sistema-mundo moderno/colonial, un patrón de poder republicano de corte liberal; mismo que seguía dejando por fuera la complejidad de los mundos africanos o del medio oriente y que no "calzaba" con las realidades de la América Hispánica, pues a pesar del casi total exterminio de las culturas originarias, la trata de personas esclavizadas; las divisiones sociales, territoriales, simbólicas y de castas, pervivían las subalternidades y múltiples las maneras de comprender ancestralidades, territorios y culturas.

Periódicos e instrucción pública

Varios eran los desafíos que afrontaban los republicanos letrados: una población cada vez más numerosa, inmersa en dualidad de ser concebidos como pueblo y como plebe, con la necesidad de ser instruidos para los fines económicos del nuevo Estado, sin el estatus de ciudadanos que la egalite, fraternite, liberte, otorgaba a los ilustrados. Esta misma población requería un lugar y una ocupación dentro del nuevo orden, cercanos a la producción, a los tributos y a los censos, al tiempo que distantes de congresos, presidencias, funciones públicas, pero cercanos a las obligaciones en ejércitos, impuestos y productividad.

Otra desafío era la concepción en torno a la instrucción pública, para El Libertador, debía garantizarse el valor moral, por encima, incluso de la política.

Para Bolívar la educación y la Instrucción Pública debían estar regidas por un 'poder moral' con jurisdicción efectiva sobre ellas, debían ser la prioridad de todo gobierno republicano (...) el poder moral debe someter a la Instrucción Pública y a la educación, sometimiento que despliega una serie de dominaciones: el hombre moral sobre el hombre político (...) la moral sobre la ley, dado que se trata de instituciones morales supra-estatales, es decir, ipor encima de cualquier institución de la sociedad civil o la sociedad política! (Echeverry, 1989, pp. 37-38)

Bolívar retomó el areópago griego, para representar una suerte de juez superior, aún por encima de la sociedad política y la sociedad civil, para discernir y arbitrar sobre el deber ser moral al interior de la república, capaz de ejercer "autoridad plena e independiente sobre las costumbres públicas, y sobre la primera educación”, como lo publicó El Fosforo ${ }^{13}$, en abril de 1823. Se intentaba entonces constituir a la policía del discurso (Echeverry, 1989 , p. 40), capaz de censurar desde la moral, a la élite letrada republicana, en nombre de un cuerpo colegiado que tendría como valor superior la moral, la patria y la religión. 


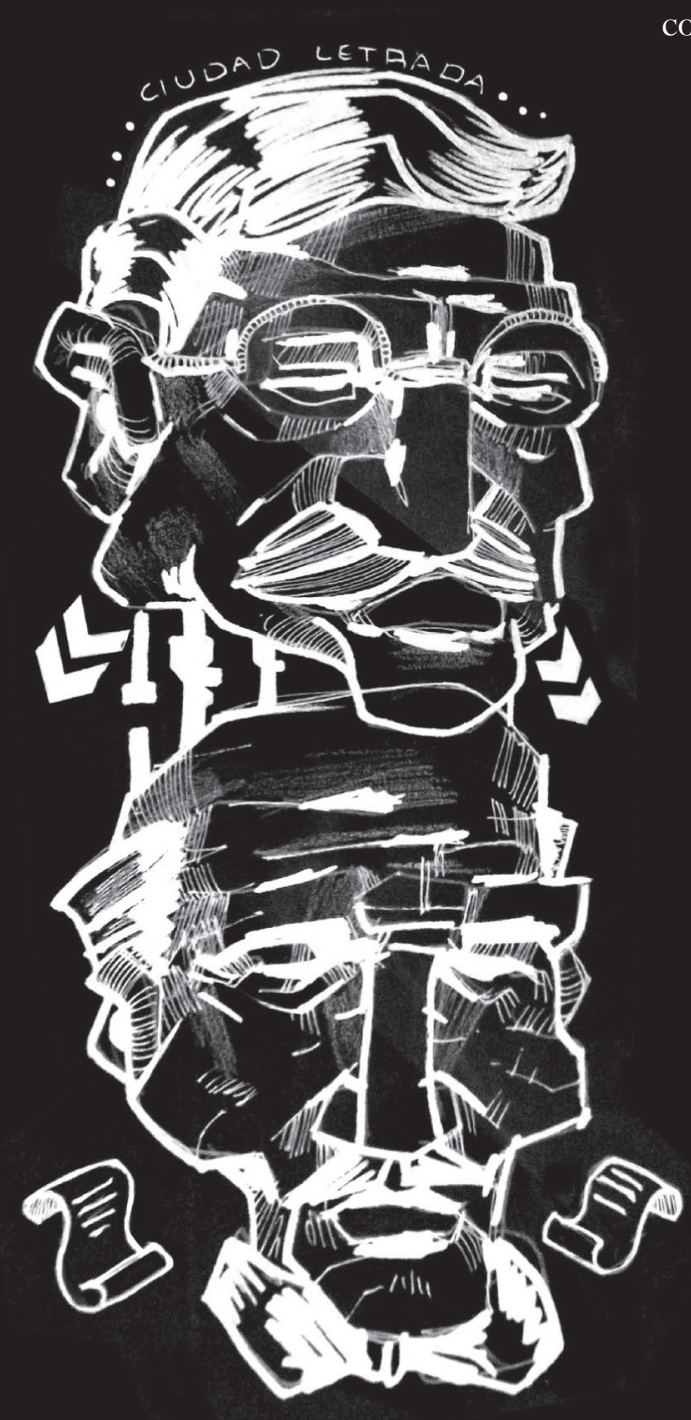

Se constituye por medio de los censores en un infatigable ojo vigilante de la ley; los censores en su conjunto se denominan policías morales, el mejor censor recibirá el título de catón. El areópago es $\mathrm{n}$ instrumento de cálculo y medida, siendo el encargado de llevar una estadística de la moral en la república; es la meda en que no se distingue entre la moral pública y la moral privada, se pretende cuantificar y dar a la luz pública los comportamientos que circulan en el ámbito de lo privado,

con esta finalidad se le exige a las instituciones encargadas de la penalización de los comportamiento ilícitos de los ciudadanos, entregar una aritmética exacta de las causas de estas infracciones. (Echeverry, 1989, p. 41)

El areópago fue hábilmente reemplazado por la sociedad literaria promovida por Santander y sus allegados. La función de la sociedad, más que de censura o penalización, sería la de consejería para la instrucción pública. En este escenario, las sociedades literarias como parte de las sociedades patrióticas que eran promovidas desde la vicepresidencia, eran reguladas por el Congreso, mismo que rechazaba la realización de cualquier tipo de organización popular en tanto podrían llegar a limitar la libertad, el poder y distanciarse de "la difusión de la ilustración y las luces" (Echeverry, 1989, p. 88).

La instrucción pública, junto a la prensa, logró posicionarse como regularidad discursiva y correlato del discurso republicano. En el proceso, contribuyó en el diseño de saberes, planes de estudio, elaboración del presente (y pasado) del nuevo Estado, selección de ideólogo y pensadores, que contribuían tanto al moldeamiento de subjetividades de ciudadanos republicanos, como al moldeamiento de subjetividades gubernamentales, logrando simultáneamente la imposición, el control y la centralización de las instancias nacionales y provinciales del ejercicio y la administración pedagógica.

Pero los habitantes de la ciudad letrada no compartían los mismos intereses, de hecho las murallas se habían resquebrajado: no era el territorio exclusivo de los ilustres criollos santafereños, en la segunda década decimonónica, los bogotanos se vieron desplazados por miembros del partido libertador, así como por ilustres criollos de la periferia, comerciantes, legisladores republicanos (que a su vez estaban divididos en varias facciones).

La matriz colonial había cambiado de traje discursivo: la república. Leyes, ordenamientos, subjetividades y territorios alcanzaban estatus de libertad, igualdad y fraternidad. Casi a manera de eslogan, se repetían los principios de la Revolución Francesa en decretos, comisiones para la instrucción pública y libertad de imprenta, mientras en la práctica, continuaban las fronteras letradas que se repetían y publicaban en la prensa decimonónica. 
Este tema que debe conver tirse en reflexión para investigadores sociales y comunicólogos, así como para indagaciones transversales e interdisciplinares, en tanto entre los años 2010 y 2030, se conmemoran doscientos años de prensa republicana y con ello, una invaluable oportunidad de recapacitar en torno al papel que los medios han jugado en la historia y la historia que han reflejado los medios. También podría permitir el reconocimiento de vacíos sobre lo que comprendemos como "nuestro pasado", o sobre lo que creemos es el ejercicio ciudadano en nuestros días. Asimismo, podría significar la re-visión de enunciados que encubren estereotipos y que se emplean y difunden sin mayor criterios en piezas y contenidos comunicacionales. De otro lado, este tiempo nos puede posibilitar un camino de renovadas preguntas para que generaciones futuras puedan tener una interpretación renovada del pasado, conforme a los desafíos y realidades venideras.

\section{Notas}

${ }^{1}$ El artículo hace parte de los hallazgos de la investigación doctoral Prensa/Poder/Subalternidades. Nación y Cultura en la Republica Letrada de Colombiana entre 1819-1830.

${ }^{2}$ Se conservan las expresiones del texto original.

${ }^{3}$ Instalada el febrero de 1819 en Angostura, ciudad venezolana que actualmente se llama Bolívar, en homenaje al Prócer.

${ }^{4}$ Tomado de la Edición del 18 de diciembre de 1819. Se respeta redacción y sintaxis del texto original. Página 109.

${ }^{5}$ Se respeta la sintaxis original. El archivo trabajado hace parte de la publicación digital en la página web de la Biblioteca Luis Ángel Arango del Banco de la República. Consultado Enero de 2012. http: / /www.banrepcultural.org/blaavirtual/exhibiciones/humboldt/home.htm

${ }^{6}$ Se respetan las cursivas del texto original.

${ }^{7}$ El trabajo de Renán Silva es uno de los más emblemáticos sobre este periódico. Prensa y Revolución a finales del siglo XVIII. Contribución a un análisis de la formación de la ideología de Independencia nacional. La Carreta Editores. Medellín.

${ }^{8}$ Semanario del Nuevo Reino de Granada. Tomo. 3. Pág. 22. El archivo trabajado hace parte de la publicación digital en la página web de la Biblioteca Luis Ángel Arango del Banco de la República. Consultado septiembre 19 de 2011 http://www.banrepcultural.org/blaavirtual/exhibiciones/humboldt/home.htm

${ }^{9}$ Semanario del Nuevo Reino de Granada. Tomo. 3. Pág. 22. El archivo trabajado hace parte de la publicación digital en la página web de la Biblioteca Luis Ángel Arango del Banco de la República. Consultado septiembre 19 de 2011 http://www.banrepcultural.org/blaavirtual/exhibiciones/humboldt/home.htm

${ }^{10}$ Correo Curioso No 9. 14-IV-1801. "Historia Natural y tabla de probabilidades de la duración de la vida humana".

${ }^{11}$ Se respeta la sintaxis del original. El archivo trabajado hace parte de la publicación digital en la página web de la Biblioteca Luis Ángel Arango del Banco de la República. Consultado Octubre 8 de 2011. http://www.banrepcultural.org/blaavirtual/exhibiciones/humboldt/home.htm

${ }^{12}$ Se respeta la sintaxis del original. El archivo trabajado hace parte de la publicación digital en la página web de la Biblioteca Luis Ángel Arango del Banco de la República. Consultado septiembre 6 de 2011. http://www.banrepcultural.org/blaavirtual/exhibiciones/humboldt/home.htm. La alusión a las canas, así como a (Nicolás de) Bara Sorda y Mena, hacen referencias a represalias del poder eclesiástico en el siglo XVIII, por tanto puede interpretarse como una figura metafórica para indicar personajes e ideas anticuadas, desactualizadas, lugar donde quiere ubicar Santander al Precursor.

${ }^{13}$ El Fósforo de Popayán. Jueves 10 de abril de 1823. No. 11. Primer Semestre. Págs. 45b. Archivo de la Hemeroteca digital de la Biblioteca Luis Ángel Arango. Banco de la República. Colombia. El texto completo hace parte de las memorias del Congreso del mismo año y es publicado en su totalidad por El Fósforo. 


\section{Referencias}

Aguilar J. A. \& Rojas R. Coordinadores. (2002). El republicanismo en Hispanoamérica. Ensayos de historia intelectual y política. México: Fondo de Cultura Económica - CIDE.

Arroyo, I. (2002). La República Imaginada. En Aguilar J. A. y Rojas R. (Coords.). El republicanismo en Hispanoamérica. Ensayos de historia intelectual y política. México: Fondo de Cultura Económica CIDE.

Arboleda, S. (2004). Intelectualidades afrocolombianas: pasos silenciados y senderos palpitantes. Propuesta de postulación al Doctorado en Estudios Culturales Latinoamericanos, Quito, UASB.

Bolívar, S. ([1815]; 2008). Carta de Jamaica. Colección Correspondencia, biografías y autobiografías. Libros en Red. Recuperado de http: / /www.librosenred.com. Consultado última vez noviembre 08 de 2014.

Bushnell, D. ([1954]; 1985). El régimen e Santander en la Gran Colombia. Bogotá: El Áncora Editores.

Castro S. (2005). Ciencias sociales, violencia epistémica y el problema de la 'invención del otro. En Lander E. (comp.), La colonialidad del saber: eurocentrismo y ciencias sociales. Perspectivas Latinoamericanas. (pp. 153 - 172). La Habana: Editorial de Ciencias Sociales.

Dussel, E. (2005). Europa, modernidad y eurocentrismo. En Lander E. (comp.), La colonialidad del saber. (pp. 41 - 56). La Habana: Editorial de Ciencias Sociales.

. (2001). Eurocentrismo y modernidad (Introducción a las lecturas de Frankfurt). En Mignolo W. (comp.), Capitalismo y geopolítica del conocimiento. El Eurocentrismo y la filosofía de la liberación en el debate intelectual contemporáneo. Buenos Aires: Ediciones del Signo.

.(2005). Transmodernidad e Interculturalidad (Interpretación desde la Filosofía de la Liberación). Ciudad de México: UAM.

(1994). 1492: el encubrimiento del otro: hacia el origen del mito de la modernidad. La Paz: UMSA. Facultad de Humanidades y Ciencias de la Educación. Plural Editores. También disponible en http://biblioteca.clacso.edu.ar. http://bibliotecavirtual.clacso.org.ar/clacso/ otros/20111218114130/1942.pdf. Última consulta: septiembre 12 de 2013.

Echeverry S. Alberto. (1989). Santander y la Instrucción Pública (1819-1840). Foro Nacional Por Colombia. Universidad de Antioquia.

Foucault, M. ([1976] 1987). Historia de la sexualidad. La voluntad de saber. México: Siglo XXI Editores. . ([1970] 2007). La arqueología del saber. Traducción de Aurelio Garzón del Camino. $2^{\text {a }}$ ed. Rev. México: Siglo XXI Editores.

Garrido, M. (2010). Palabras que nos cambiaron: lenguaje y poder en la independencia. Bogotá: Biblioteca Luis Ángel Arango. Catálogo de la exposición celebrada en la Biblioteca Luis Ángel Arango.

Hall, S. (1972). "Encoding/Decoding." Culture, Media, Languaje.Working Papers in Cultural Studies, 1972-79. London: Hutchinson.

Helg, A. (2011). Libertad e igualdad en el Caribe colombiano. 1770-1835. Medellín: Fondo Editorial Universidad EAFIT. Banco de la República.

Loaiza, G. (2011). Sociabilidad, religión y política en la definición de la nación. Colombia, 1820-1886. Bogotá: Centro de Estudios en Historia. Universidad Externado.

Maiguashca, J. (Ed.). (1994). Historia y región en el Ecuador. 1830-1930. Quito: Flacso Sede Ecuador. Corporación Editora Nacional.

Marín, J. M. (2008). Gente decente. La elite rectora de la capital. 1797-1803. Bogotá: Instituto Colombiano de Antropología e Historia, ICANH.

Mejía, S. (2007). La Revolución en letras. La historia de la revolución de Colombia, José Manuel Restrepo (17811863). Bogotá: Ediciones Uniandes - Universidad EAFIT.

Mignolo, W. (2000). Diferencia colonial y razón postoccidental. En La reestructuración de las ciencias sociales en América Latina. Bogotá: Instituto Pensar/Centro Editorial Javeriana.

. (2003). Historias locales / Diseños globales. Madrid: Akal. 
Noboa, P. (2005). La matriz colonial, los movimientos sociales y los silencios de la modernidad. En Walsh C. (Ed.), Pensamiento crítico y matriz (de) colonial. Reflexiones Latinoamericanas. Quito: Ediciones Abya Yala.

Ortega, F. A. \& Chaparro S. A. (Eds.). (2012). Disfraz y pluma de todos. Opinión pública y cultura política, siglos XVIII y XIX. Bogotá: Universidad Nacional de Colombia. Sede Bogotá. University of Helsinky. Lecturas CES.

Palti, J. (2005). La invención de una legitimidad. Razón y retórica en el pensamiento mexicano del siglo XIX (un estudio sobre las formas de discurso político). México: Fondo de Cultura Económica.

Quijano, A. (2000). Colonialidad del Poder y Clasificación Social. En Journal of worl-sistem resarch. V. 2. Summer/fall. p. 342-386. Special Issue: Immanuel Wallerstein -Part I. Recuperado de http:// www.jwsr.org/wp-content/uploads/2013/05/jwsr-v6n2-quijano.pdf. Consultado mayo 2011.

Quijano, A. (1999). Colonialidad del poder, cultura y conocimiento en América Latina. En Castro, S., Guardiola, O., \& Millán, B. C (Eds.), Pensar (en) los intersticios. Teoría y práctica de la crítica poscolonial. Bogotá: Pontificia Universidad Javeriana.

. (2000). Colonialidad del poder, globalización y democracia. Caracas: Escuela de Estudios Internacionales y diplomáticos "Pedro Gual".

. (2005). Colonialidad del poder, eurocentrismo y América latina. En La colonialidad del saber: eurocentrismo y Ciencias Sociales. Perspectivas Latinoamericanas. (pp. 216-271). La Habana: Editorial de Ciencias Sociales.

Rama, A. (1998). La Ciudad Letrada. Montevideo: Ediciones Arca.

Restrepo, J. M. ([1858] 1969). Historia de la Revolución de Colombia. Tomos I y II. Medellín: Editorial Bedout. Rodríguez I. (1998). Hegemonía y Dominio: Subalternidad, un significado Flotante. En Castro, S. \& Mendieta, E. (Eds.), Teorías sin disciplina (latinoamericanismo, poscolonialidad y globalización en debate). México: Miguel Ángel Porrúa Disponible en versión digital: http://www.ensayistas. $\mathrm{org} / \mathrm{critica} /$ teoria/castro/rodriguez.htm. Última consulta: noviembre 05 de 2013.

Rojas, Cristina. (2001). Civilización y Violencia. La búsqueda de la identidad en la Colombia del siglo XIX. Colección Vitral. Editorial Norma. Bogotá.

Sancholuz, C. (2005). Ficciones de la puertorriqueñidad. Construcciones discursivas de las identidades nacionales en la obra de Edgardo Rodríguez Juliá y Manuel Ramos Otero. Tesis presentada para la obtención del grado de Doctora en Letras. Universidad de La Plata. Recuperado de: http: / /www. fuentesmemoria.fahce.unlp.edu.ar/tesis/te.193/te.193.pdf. Consultado nov. 2014

Silva, R. ([1988] 2004). Prensa y Revolución a finales del siglo XVIII. Contribución a un análisis de la formación de la ideología de Independencia nacional. Medellín: La Carreta Editores.

. (2002). Los ilustrados de Nueva Granada 1760-1808. Genealogía de una comunidad de interpretación. Medellín: Fondo Editorial EAFIT. Banco de la República.

Walsh, C. (2002a). Las geopolíticas de conocimiento y colonialidad del poder. Entrevista a Walter Mignolo. En Walsh, C., Schiwy, F. \& Castro, S. (Eds.), Indisciplinar las ciencias sociales. Quito: Abya Yala, UASB.

(2002b). La (re)articulación de subjetividades políticas y diferencia colonial en Ecuador: reflexiones sobre el capitalismo y las geopolíticas del conocimiento. En Walsh, C., Schiwy, F. \& Castro, S. (Eds.), Indisciplinar las ciencias sociales. Quito: Abya Yala, UASB.

(1979). El Moderno Sistema Mundial. La agricultura capitalista y los orígenes de la economía-mundo europea en el siglo XVI. Madrid: Siglo XXI Editores.

Recibido: noviembre 15 / Aprobado: noviembre 30 de 2014 